\title{
Gene Augmentation for X-Linked Retinitis Pigmentosa Caused by Mutations in RPGR
}

\author{
William A. Beltran ${ }^{1}$, Artur V. Cideciyan², Alfred S. Lewin ${ }^{3}$, William W. Hauswirth ${ }^{4}$, \\ Samuel G. Jacobson ${ }^{2}$, and Gustavo D. Aguirre ${ }^{1}$ \\ ${ }^{1}$ Section of Ophthalmology, School of Veterinary Medicine, University of Pennsylvania, Philadelphia, \\ Pennsylvania 19104 \\ ${ }^{2}$ Scheie Eye Institute, Department of Ophthalmology, University of Pennsylvania Perelman School \\ of Medicine, Philadelphia, Pennsylvania 19104 \\ ${ }^{3}$ Department of Molecular Genetics \& Microbiology, University of Florida, Gainesville, Florida 32610 \\ ${ }^{4}$ Department of Ophthalmology, University of Florida, Gainesville, Florida 32610 \\ Correspondence:wbeltran@vet.upenn.edu
}

X-linked retinitis pigmentosa (XLRP) caused by mutations in the RPGR gene is a severe and early onset form of retinal degeneration, and no treatment is currently available. Recent evidence in two clinically relevant canine models shows that adeno-associated viral (AAV)-mediated RPGR gene transfer to rods and cones can prevent disease onset and rescue photoreceptors at early- and mid-stages of degeneration. There is thus a strong incentive for conducting long-term, preclinical efficacy and safety studies, while concomitantly pursuing the detailed phenotypic characterization of XLRP disease in patients that may benefit from such corrective therapy.

X-linked retinitis pigmentosa (XLRP) in-
cludes some of the earliest onset and rapidly
progressive forms of inherited retinal degen-
erations, and accounts for $6 \%-20 \%$ of all cases
of retinitis pigmentosa (Fishman 1978; Jay
1982; Breuer et al. 2002). XLRP has been ge-
netically mapped to six loci (RP2, RP3, RP6,
RP23, RP24, and RP34); of these, RP3, which
is associated with mutations in the retinitis
pigmentosa GTPase regulator (RPGR) gene, is
the predominant subtype (Meindl et al. 1996;
Roepman et al. 1996). Indeed, mutations in
$R P G R$ are found in $>70 \%$ of families affected
by XLRP and $\sim 15 \%$ of simplex retinitis pig- mentosa cases (Bader et al. 2003; Sharon et al. 2003; Pelletier et al. 2007; Branham et al. 2012). Over the past decade, substantial effort has been dedicated to unveiling RPGR's function in photoreceptors, identifying novel mutations and the spectrum of disease phenotypes in humans, and characterizing small and large animal models of RPGR-XLRP that could be used to test novel therapeutic approaches. This review will primarily focus on the results of the preclinical studies conducted in canine models, as these provide strong evidence that a corrective gene therapy for XLRP may become a reality in the not-so-distant future.

Editors: Eric A. Pierce, Richard H. Masland, and Joan W. Miller

Additional Perspectives on Retinal Disorders: Genetic Approaches to Diagnosis and Treatment available at

www.perspectivesinmedicine.org

Copyright (C) 2015 Cold Spring Harbor Laboratory Press; all rights reserved; doi: 10.1101/cshperspect.a017392

Cite this article as Cold Spring Harb Perspect Med 2015;5:a017392 
W.A. Beltran et al.

\section{RPGR AND ITS ROLES IN THE PHOTORECEPTOR CONNECTING CILIUM}

The RPGR gene (172 kb) was initially described as containing 19 exons, and mutations in RPGR $^{\text {ex1-19 }}$ accounted for only $15 \%-20 \%$ of XLRP patients (Meindl et al. 1996). Subsequently, an alternatively spliced carboxy-terminal exon called ORF15 was identified and found to be a hot spot for microdeletions, frameshift mutations, and premature stop mutations (Vervoort et al. 2000). Of the more than 350 RPGR mutations reported to date, $>55 \%$ are found in exon ORF15 (see http://rpgr.hgu.mrc.ac.uk).

Among the different splice variants (Vervoort et al. 2000; Neidhardt et al. 2007; Schmid et al. 2010), RPGR $\mathrm{exl-ORF15}^{\text {and constitutive }}$ RPGR $^{\text {ex1-19 }}$ are the most abundantly expressed RPGR isoforms in the retina. Both proteins have been immunolocalized to photoreceptor connecting cilium of both rods and cones (Hong et al. 2003; Wright et al. 2011). One

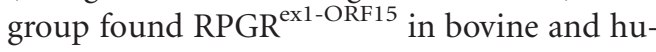
man photoreceptor outer segments (Roepman et al. 2000; Mavlyutov et al. 2002), although this was later disputed (Hong et al. 2003). The different temporal pattern of retinal expression of these two isoforms suggests that RPGR ${ }^{\text {ex1-19 }}$ may play a role in photoreceptor development whereas RPGR ${ }^{\text {ex1-ORF15 }}$ may be necessary for maintaining the integrity of mature photoreceptors (Wright et al. 2011). The constitutive

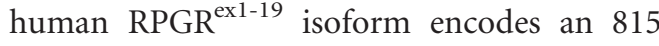
amino acid protein (MW: $90-100 \mathrm{kDa}$ ) that is widely expressed, whereas the full-length human RPGR ${ }^{\text {ex1-ORF15 }}$ isoform, which encodes a 1152 amino acid, soluble protein (MW: 200$220 \mathrm{kDa}$ ), has been found predominantly in photoreceptors.

Both isoforms contain a common aminoterminal RCC1-like domain (Meindl et al. 1996) (encoded by exons 2 to 11), which has recently been shown to play the role of a guanine nucleotide exchange factor (GEF) by directly interacting with the GDP-bound form of the small GTPase RAB8A (Murga-Zamalloa et al. 2010a). RPGR has also been shown to interact directly or via molecular complexes with the following proteins: PDE6d (Linari et al. 1999); a number of ciliary proteins, including RPGRinteracting protein 1 (RPGRIP1) (Boylan and Wright 2000; Roepman et al. 2000; Hong et al. 2001); the nephrocystins NPHP1 (Murga-Zamalloa et al. 2010b), NPHP4 (Murga-Zamalloa et al. 2010b), NPHP5/IQCB1 (Otto et al. 2005), NPHP6/CEP290 (Chang et al. 2006), and NPHP8/RPGRIP1L (Khanna et al. 2009); the chromosome-associated proteins SMC1 and SMC3 (Khanna et al. 2005); the centrosomal protein NPM1 (Shu et al. 2005); and proteins associated with intraflagellar transport (Tg737/ Polaris/IFT88) and microtubule motors (dynactin subunits, kinesin-II) (Khanna et al. 2005). Exon ORF15 encodes for a highly repetitive, glutamic acid-rich region whose function is currently unknown, yet its carboxyl terminus has been recently shown to interact with whirlin, which is a member of the Usher interactome (Wright et al. 2012). Localization of RPGR to the sensory cilia of photoreceptors (Hong et al. 2003) and its interaction with numerous complexes involved in protein transportation suggest that RPGR plays a role in regulating protein trafficking between the inner and outer segments at the level of the connecting cilium; however, its exact molecular function is still poorly understood.

Recent reports have suggested that RPGR may contribute to the biogenesis and maintenance of photoreceptor cilia and the transitional zone of motile cilia (Murga-Zamalloa et al. 2010a; Gakovic et al. 2011; Ghosh et al. 2011). This role is consistent with the occurrence of hearing dysfunction, respiratory infections, and cilia dyskinesis in some rare cases of syndromic RPGR-XLRP (van Dorp et al. 1992; Iannaccone et al. 2003; Koenekoop et al. 2003; Zito et al. 2003; Iannaccone et al. 2004; Moore et al. 2006; Bukowy-Bieryllo et al. 2013).

\section{RETINAL DEGENERATION PHENOTYPE OF XLRP PATIENTS WITH RPGR MUTATIONS}

A range of clinical diagnoses has been associated with $R P G R$ mutations that cause progressive retinal degeneration of photoreceptors. RPGRassociated retinal degeneration most commonly presents in males of XLRP families or in simplex 
males as early loss of night vision and peripheral vision, abnormal electroretinograms, and relatively better retention of central vision in younger patients (Meindl et al. 1996; Roepman et al. 1996; Vervoort et al. 2000; Sandberg et al. 2007; Zahid et al. 2013). Less commonly, there is early involvement of the fovea and loss of visual acuity. Depending on the degree of abnormality in retina-wide measurements of cone versus rod function, clinical diagnoses have included Xlinked cone-rod dystrophy, cone dystrophy, or macular degeneration (Mears et al. 2000; Ayyagari et al. 2002; Demirci et al. 2002; Yang et al. 2002; Ebenezer et al. 2005; Pelletier et al. 2007; Thiadens et al. 2011; Beltran et al. 2012). Retinally colocalized measures of function have often shown both rod and cone loss (Jacobson et al. 1997; Lorenz et al. 2003; Huang et al. 2012) consistent with expression of the RPGR gene product in rod and cone cilia (Hong et al. 2000, 2003; Roepman et al. 2000; Khanna et al. 2005; Shu et al. 2005). High allelic heterogeneity has been implied as cause for the spectrum of severity and phenotypes encountered between families carrying different $R P G R$ mutations, and there is evidence that genetic modifiers may contribute to intra-familial phenotypic divergence (Keith et al. 1991; Walia et al. 2008; Ruddle et al. 2009; Fahim et al. 2011).

Carrier females with RPGR mutations also show a wide spectrum of retinal disease expression ranging from asymptomatic with normal electrophysiological and psychophysical test results to very severe retina-wide disease (Andreasson et al. 1997; Jacobson et al. 1997; Weleber et al. 1997; Bauer et al. 1998; Fishman et al. 1998; Flaxel et al. 1999; Ayyagari et al. 2002; Lorenz et al. 2003; Ebenezer et al. 2005; Jin et al. 2006; Ruddle et al. 2009; Thiadens et al. 2011). There tends to be significant interocular asymmetry of disease severity in most carriers (Jacobson et al. 1989; Weleber et al. 1997; Fishman et al. 1998; Lorenz et al. 2003; Ebenezer et al. 2005). A distinct golden tapetal-like reflex, hypothesized to be located at cone inner segments (Cideciyan and Jacobson 1994), or peripheral photoreceptor outer segments (Berendschot et al. 1996), has been variably described in a subset of female carriers of RPGR mutations (Andreas- son et al. 1997; Jacobson et al. 1997; Weleber et al. 1997; Bauer et al. 1998; Fishman et al. 1998; Flaxel et al. 1999; Ayyagari et al. 2002; Lorenz et al. 2003; Ebenezer et al. 2005; Jin et al. 2006; Ruddle et al. 2009; Thiadens et al. 2011).

\section{ANIMAL MODELS OF RPGR-XLRP}

\section{Murine Models}

The description of the phenotypes of several mouse models of RPGR disease, including XLRP (Hong et al. 2000, 2004; Brunner et al. 2010; Wright et al. 2011; Huang et al. 2012; Thompson et al. 2012) and cone-rod dystrophy (Brunner et al. 2010), have been published. Evidence that mice sharing the same RPGR mutation but on a different genetic background can express a different disease phenotype further highlights the potential role of genetic modifiers (Brunner et al. 2010). Overexpression of the RPGR ${ }^{\text {ex1-19 }}$ isoform in photoreceptor cells of transgenic mice leads to early onset (2 months of age) degeneration, whereas no retinal alterations are associated with overexpression of the RPGR ${ }^{\text {ex1-ORF15 }}$ isoform (Wright et al. 2011). This finding further supports the claim that the severe phenotype described in a transgenic mouse expressing a truncated RPGR ex1-ORF15 $^{\text {ex }}$ isoform is caused by a toxic gain-of-function and not to the overexpression of the transgene (Hong et al. 2004). With the exception of this transgenic model that shows rapid kinetics of photoreceptor loss, the other RPGR mutant mice, including the naturally occurring $R d 9$ mouse (Thompson et al. 2012) that could be used to test a gene augmentation therapy strategy, show a slowly progressive photoreceptor degeneration resulting in retention of $>50 \%$ outer nuclear layer thickness by 2 years of age (summarized in Huang et al. 2012, Supplementary Table S1, see http://www.iovs.org/lookup/ suppl/doi:10.1167/iovs.12-10070/-/DCSupple mental).

\section{Canine Models}

To date, the XLPRA1 and XLPRA2 dogs are the only identified large animal models of 
W.A. Beltran et al.

RPGR-XLRP. Although both diseases are caused by nearby microdeletions in the same exon ORF15, they show distinct ages of onset, rates of progression, and spatiotemporal distribution of retinal degeneration.

In XLPRA1, a five nucleotide deletion in exon ORF15 (c.1028-1032delGAGAA; GeneBank accession no. AF385621) introduces an immediate premature stop codon, and the putative protein has 230 amino acids truncated at its carboxyl-terminal end (Zhang et al. 2002). This deletion causes a rod-cone degeneration detectable by histology and electroretinogram in juvenile hemizygote male dogs (approximately one year of age) that progresses from the peripheral to the central retina (Zeiss et al. 1999; Beltran et al. 2012). Even though the research colony has been established from a single affected male, the extent of severity of the retinal changes, and their rate of progression varies from one individual to another even in animals of the same age (Zeiss et al. 1999; Guyon et al. 2007; Beltran et al. 2012), suggesting that genetic modifiers which have been implicated in humans with RPGR-XLRP (Fahim et al. 2011) may also be responsible for this variability in disease phenotype. As a result of random X-inactivation (also called lyonization), heterozygous female dogs undergo a patchy form of retinal degeneration (Zeiss et al. 1999; Beltran et al. 2009) that is the result of loss of photoreceptors that are clonally derived from a progenitor cell expressing the mutant XLPRA1 allele. This mosaic pattern of retinal degeneration, which is histologically detectable at $1.4 \mathrm{yr}$ and is still apparent in 7.8-yr-old dogs, resembles the phenotype reported in human XLRP carriers (Szamier and Berson 1985; Jacobson et al. 1997; Aguirre et al. 2002; Vajaranant et al. 2002).

A second form of canine RPGR-XLRP, termed XLPRA2, is caused by a two nucleotide deletion in ORF15 (c.1084-1085delGA) (Zhang et al. 2002). This microdeletion introduces a frameshift followed by a premature stop codon. The putative protein includes 34 additional basic residues and an increased isoelectric point (4.30 vs. 4.01 ). XLPRA2 retinas undergo early ( 4 weeks of age) disorganization of photoreceptor outer segments, which is followed by increased cell death that peaks at about 7 weeks of age before returning, at 12 weeks, to a reduced yet constant rate. These photoreceptor cell death kinetics result in rapid outer nuclear layer thinning, that leads to an average thickness of three rows of nuclei by 41 weeks of age. Early cone disease has been shown to occur in the newly discovered canine fovea-like area (Beltran et al. 2014a). Mislocalization of rod opsin, short-wavelength (blue) cone opsin, and middle/long-wavelength (red/green) opsin are other early events that suggest that this canine ciliopathy affects all populations of photoreceptors. Similar evidence for altered protein trafficking through the connecting cilium has been reported in murine models (Hong et al. 2000, 2005; Brunner et al. 2010; Wright et al. 2011; Thompson et al. 2012), and in a carrier patient of XLRP (Adamian et al. 2006). Initiation of photoreceptor loss is accompanied by early retinal remodeling events such as rod neurite sprouting, retraction of rod bipolar dendrites, and Müller cell gliosis. Subsequently, other inner retinal remodeling events, including altered labeling of cell-specific markers of horizontal and amacrine cells, and loss of normal inner plexiform lamination follows (Beltran et al. 2006). Despite the severe progression of the disease, particularly in the central (visual streak) area (Beltran et al. 2012), dogs at 41 weeks of age retain sufficient rod- and cone-mediated visual function to navigate without difficulties in an obstacle avoidance course (WA Beltran, unpubl.). Similarly to XLPRA1 carriers, XLPRA2 heterozygous mutant dogs undergo random $\mathrm{X}$ inactivation during embryogenesis that results in a patchy form of retinal degeneration (Fig. 1). However, unlike XLPRA1, the focal areas of cell loss do not persist. Indeed, improved outer nuclear layer lamination, loss of opsin mislocalization, and improved morphology of the outer plexiform layer and rod bipolar cell dendrites in older carriers suggests that retinal plasticity in the young XLPRA2 carriers allows tangential displacement of remaining (nonmutant) photoreceptors in the depleted foci, and rewiring with postreceptoral neurons (Beltran et al. 2009). Similar lateral dispersion of photoreceptors following focal laser damage has been 
A
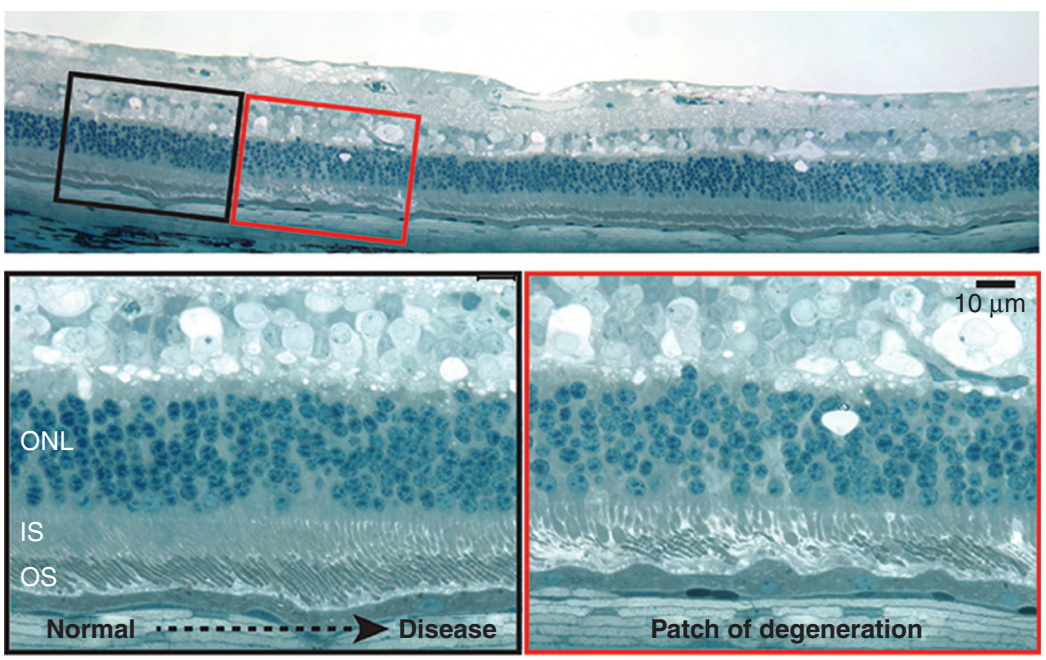

B

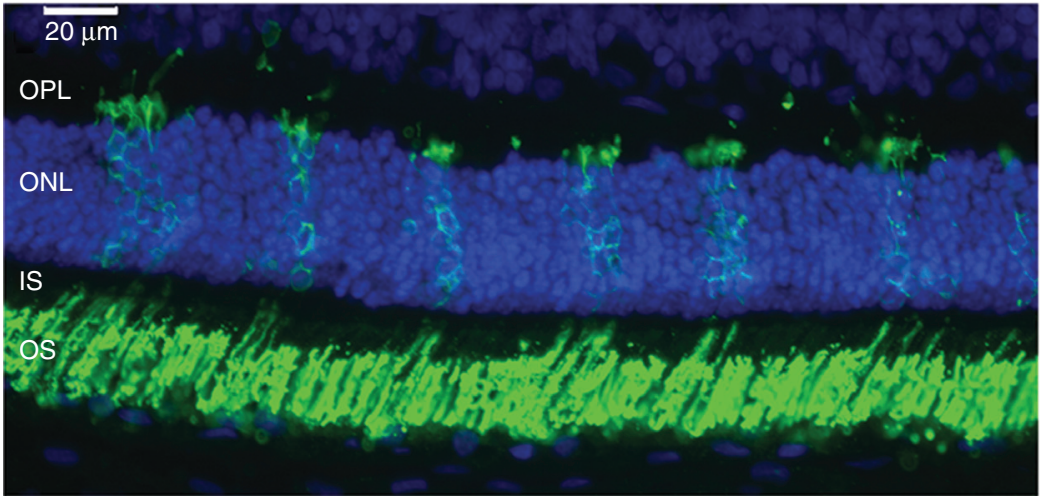

Figure 1. Mosaic pattern of retinal degeneration in XLPRA2 female carriers. (A) Focal patches of photoreceptor degeneration surrounded by normally laminated retina in a 24 -wk-old carrier. $(B)$ Numerous patches of rod opsin mislocalization to the inner segments (IS) and outer nuclear layer (ONL), and features of rod neurite sprouting in the outer plexiform layer (OPL) in a 7-wk-old carrier. (Modified from data in Figure 1 from Beltran et al. 2009).

shown in the nonhuman primate retina (Strazzeri et al. 2014).

Earlier on, we speculated that the more severe disease phenotype observed in the XLPRA2 model could be caused by a toxic gain-of-function, whereas the slower progression and delayed onset seen in XLPRA1 might be explained by a loss-of-function mechanism. These hypotheses led us to initially develop a gene augmentation strategy for the XLPRA1 disease, while preparing for the potential need to combine an alleleindependent gene knockdown and a hardened (resistant) gene replacement approach to correct the XLPRA2 phenotype (see below).

\section{OUTCOME MEASURES OF PRECLINICAL EFFICACY}

Detailed analysis of the spatiotemporal features of the two canine diseases and development of staging classifications allowed establishment of outcome measures of therapeutic intervention. These are listed in Table 1.

\section{THERAPEUTIC INTERVENTIONS: PROOF OF CONCEPT STUDIES IN CANINE MODELS OF RPGR-XLRP}

Note: All studies reported below were carried out after approval by the University of Pennsyl- 
W.A. Beltran et al.

Table 1. Outcome measures of therapeutic intervention for XLRP

\begin{tabular}{lll}
$\begin{array}{l}\text { Outcome measures of } \\
\text { photoreceptor rescue }\end{array}$ & \multicolumn{1}{c}{ Methods } & $\begin{array}{l}\text { Expected positive } \\
\text { therapeutic effect }\end{array}$ \\
\hline ONL thickness & In vivo OCT, histology & Retention \\
IS and OS structure & In vivo OCT, histology & Preservation \\
Opsin mislocalization & IHC (rod, cone opsins) & Absence \\
Rod neurite sprouting & IHC (rod opsin, synaptophysin) & Absence \\
Rod function & Scotopic ERG (a wave amplitude) & Retention \\
Cone function & Photopic ERG (30 Hz flicker) & Retention \\
Bipolar cell dendrite length & Histology & Retention \\
IPL thickness and lamination & IHC (GABA) & Retention \\
Müller cell gliosis & IHC (GFAP) & Absence \\
Postreceptoral function & Scotopic ERG (b wave amplitude) & Retention \\
\hline
\end{tabular}

ERG, electroretinogram; GFAP, glial fibrillary acidic protein; IHC, immunohistochemistry; IPL, inner plexiform layer; IS, inner segment; OCT, optical coherence tomography; ONL, outer nuclear layer; OS, outer segment.

vania IACUC, and conducted in strict accordance with the recommendations in the Guide for the Care and Use of Laboratory Animals of the National Institutes of Health, the USDA's Animal Welfare Act and Animal Welfare Regulations, and in compliance with the ARVO statement for the Use of Animals in Ophthalmic and Vision Research.

\section{Neuroprotection Fails to Rescue Photoreceptors in the XLPRA2 Dog}

Following successful demonstration of neuroprotection therapy in the $\operatorname{rcd} 1 \mathrm{dog}$ model of autosomal recessive retinitis pigmentosa (PDE6B mutation) (Tao et al. 2002), we examined whether single or repeated intravitreal injections of recombinant human ciliary neurotrophic factor (CNTF) would also modify the course of retinal degeneration in the XLPRA2 dog. Our results (Beltran et al. 2007) failed to demonstrate any positive outcome even when the compound was delivered before the peak of rod loss. However, we observed an increased number of rod opsin-positive cells in the peripheral retina, suggesting the potential for CNTF-mediated photoreceptor cell proliferation in the early postnatal XLPRA2 retina.

\section{Gene Transfer Considerations: Choice of Viral Vector, Promoters, Route of Delivery}

Among the various chimeric serotypes of recombinant adeno-associated viral (AAV) vec- tors previously used for gene transfer to the canine retina (Beltran 2009), we selected the AAV2/ 5 serotype, as it had been shown in dogs to infect both rods and cones (Weber et al. 2003; Komaromy et al. 2008; Petersen-Jones et al. 2009; Beltran et al. 2010). Photoreceptorspecific promoters that would restrict transgene expression to either rods ( $\mathrm{mOP}$, a $476 \mathrm{nt}$ segment of the proximal mouse opsin promoter), or rods and cones (hGRK1, a $292 \mathrm{nt}$ segment of the human G-protein-coupled receptor kinase 1 promoter; hIRBP, a $235 \mathrm{nt}$ segment of the human interphotoreceptor binding protein promoter) were used (al-Ubaidi et al. 1992; Beltran et al. 2010, 2012). Subretinal injections were performed with a subretinal cannula as previously reported (Komaromy et al. 2006; Beltran et al. $2010)$, and volumes injected $(70-150 \mu \mathrm{L})$ were adjusted to the dog's age and globe size, aiming to produce a bleb that covered $\sim 1 / 5-1 / 4$ of the retinal surface.

\section{Initial RPGR Gene Therapy Failures and Complications}

The first viral vector constructs that were developed and tested in XLPRA1 dogs included a shortened version of the canine RPGR $^{\text {ex1-ORF15 }}$ cDNA (cshort RPGR ${ }^{\text {ex1-ORF15 }}$ ). The decision to use this shortened RPGR transgene, which had 708 bp removed in frame from the purine-rich region of exon ORF15, was made to circumvent the DNA packaging restric- 
tion of the AAV capsid $(<4.7 \mathrm{~kb})$ in the event that a knockdown construct (small hairpin RNA or ribozyme) should need to be added to correct the XLPRA2 disease. This strategy was based on prior evidence that similar in-frame truncation of murine exon ORF15 did not eliminate its function (Hong et al. 2005). Five XLPRA1-affected dogs (four hemizygous males and homozygous mutant female) received, at 26-28 weeks of age (before the onset of retinal degeneration), a $150 \mu \mathrm{L}$ subretinal injection of either an AAV2/5-mOP-cshortRPGR ${ }^{\text {ex1-ORF15 }}$ or AAV2/5-hIRBP-cshortRPGR ${ }^{\text {ex1-ORF15 }}$ vector preparation (viral titer: $1.5 \times 10^{11} \mathrm{vg} / \mathrm{mL}$ ), or balanced salt solution. At 5-7 wk postinjection retinal examination revealed multifocal hyperreflective lesions in the treated area of five out of the six eyes that received either of the two vectors. Noninvasive imaging by optical coherence tomography showed disrupted lamination, which represented photoreceptor rosettes on histologic examination (Fig. 2) (Beltran et al. 2011, 2012). The mechanism by which transduction of photoreceptors with a shortened canine RPGR ${ }^{\text {ex1-ORF15 }}$ cDNA led to these complications was not further investigated, and it was decided instead to focus only on the gene augmentation strategy by developing and testing a viral vector that would carry instead the full-length RPGR ${ }^{\text {ex1-ORF15 }}$ transgene.

\section{Gene Augmentation with Full-Length Human RPGR ${ }^{\text {ex1-ORF15 }}$ Prevents Disease Onset in the XLPRA1 Model}

With the goal of accelerating translation of gene therapy to clinical trials, we decided to include the human rather than the canine full-length

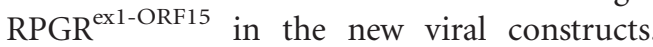
In addition, availability of antibodies directed against human RPGR (that do not crossreact with the canine isoform) would allow monitoring of therapeutic transgene expression. An AAV2/5 construct including the hRPGR ${ }^{\text {exl-ORF15 }}$ transgene under the control of the hIRBP promoter was subretinally injected in two XLPRA1 dogs at 28 weeks of age (before the onset of photoreceptor loss). Dogs were monitored by noninvasive confocal scanning laser ophthalmoscopy and spectral-domain optical coherence tomography until 77 weeks of age (well after the start of retinal degeneration). Topographical mapping of the outer nuclear layer showed increased thickness in the treated region that remained within the range seen in wild-type dogs, while significant thinning was seen in the untreated region of the same eye or in the fellow, balanced salt solution-injected control eye (Fig. 3A,B). In addition, improved backscatter signal originating from the inner/ outer segment layer was also detectable in the treated area (Beltran et al. 2012). Histological analysis confirmed the rescue of photoreceptors within the bleb area where RPGR transgene was expressed, as evidenced by an increased number of photoreceptor cells, preserved inner and outer segment structure, and absence of rod opsin and $\mathrm{R} / \mathrm{G}$ opsin mislocalization (Fig. 4A-C). This positive effect on the outer retina was also associated with improved structure of the outer plexiform layer, bipolar cells, and a lack of reactivity of Müller cells (the major glial cell population in the retina) (Fig. 4D-F). These results suggest that early intervention with corrective gene augmentation can prevent the onset of photoreceptor loss and impede deleterious secondary remodeling events in the inner retina.

Gene Augmentation with Full-Length Human RPGR ${ }^{\text {ex1-ORF15 }}$ Rescues Photoreceptors in the XLPRA2 Model When Delivered at Early and Mid-Stages of Disease

The successful outcome in the XLPRA1 model led us to test whether RPGR gene augmentation alone could also positively alter the course of photoreceptor degeneration in the earlyonset and more rapidly progressive XLPRA2 disease. An AAV2/5 construct including the hRPGR ${ }^{\text {exl-ORF15 }}$ transgene under the control of the hIRBP promoter, and one with the hGRK1 promoter, were each subretinally injected in one XLPRA2 dog at 5 weeks of age (after disease onset, but before the peak of cell death; outer nuclear layer near normal thickness). Fellow eyes were subretinally injected with balanced salt solution. Similar longitudinal analysis (up to 36 weeks of age) of outer nuclear 
W.A. Beltran et al.
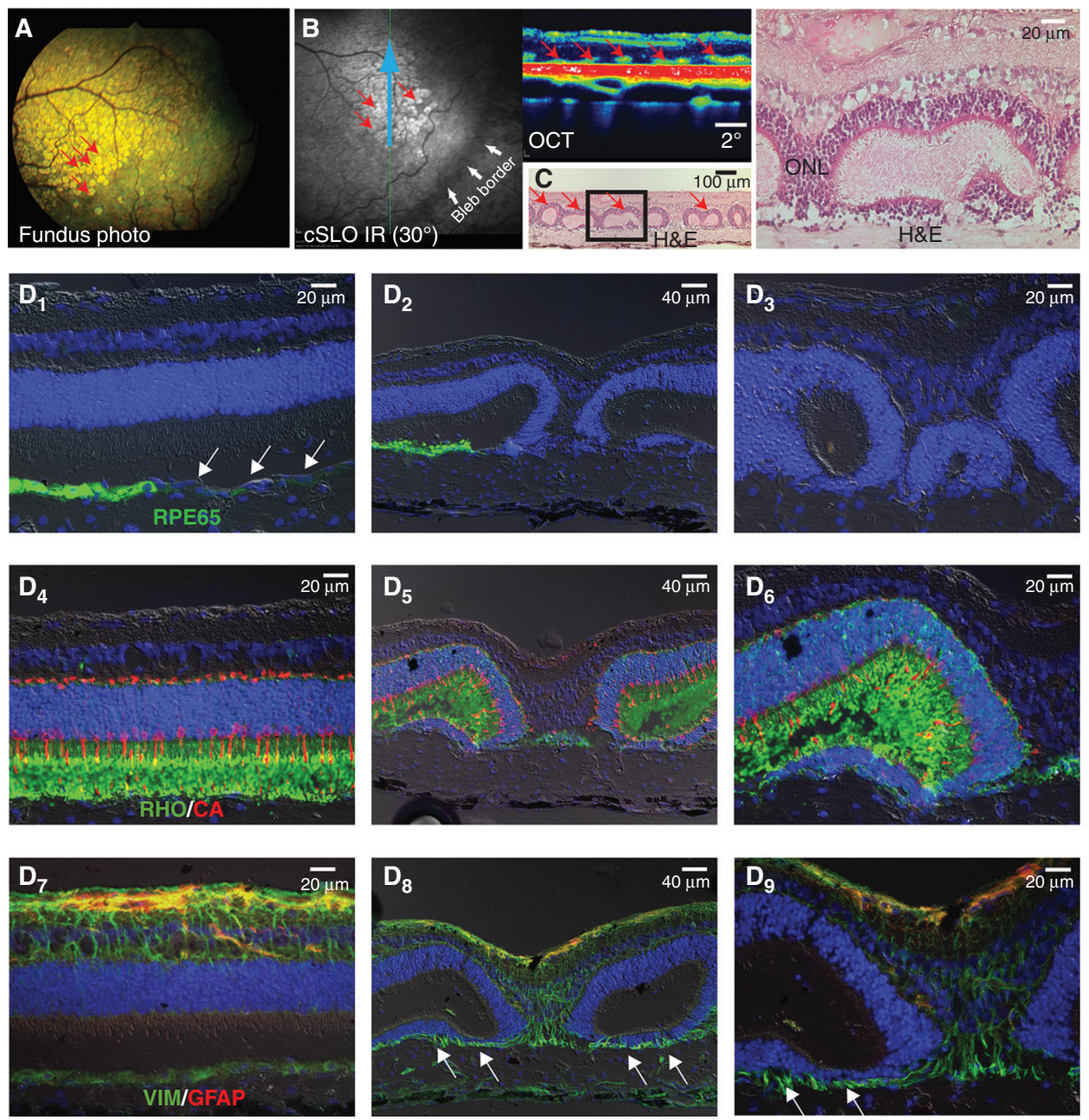

Figure 2. Retinal toxicity induced by early viral vector construct. Retinal complications in an affected XLPRA1 $\operatorname{dog} 7$ wk following subretinal injection of an AAV2/5 carrying a shortened version of canine RPGR ${ }^{\text {exl-ORF15 }}$ cDNA under the control of hIRBP promoter. (A) Multifocal hyperreflective lesions (red arrows) seen by ophthalmoscopy within the treated region. (B) Similar lesions observed by confocal scanning laser ophthalmoscopy (cSLO) and optical coherence tomography (OCT). (C) Histological features of photoreceptor rosettes, using hematoxylin and eosin ( $\mathrm{H} \& \mathrm{E})$. (D) Immunohistochemical characterization of the photoreceptor rosettes lesions. $\left(D_{1}-D_{3}\right)$ Immunolabeling (green) of the retinal pigment epithelium (RPE) is lost (white arrows) at close proximity $\left(D_{1}\right)$ and within $\left(D_{2}-D_{3}\right)$ the lesions. $\left(D_{4}-D_{6}\right)$ Normal lamination $\left(D_{4}\right)$ and structure of rods (rod opsin, green) and cones (cone arrestin, red) is disrupted within the lesions $\left(D_{5}-D_{6}\right) .\left(D_{7}-D_{9}\right)$ The normal architecture of Müller cells $\left(D_{7}\right.$, vimentin, green) is altered within the lesions $\left(D_{8}-D_{9}\right)$ with prominent extension of radial processes into the vestigial subretinal space. Limited reactivity of Müller cells (GFAP, red) is seen.

layer thickness from spectral-domain optical coherence tomography-derived topographical maps illustrated a potent rescue of photoreceptors in the treated region with the AAV2/5hIRBP- $h R P G R^{\text {exI-ORF15 }}$ vector (Fig. 3C,D), which was confirmed histologically (Fig. 5).
Treatment corrected the mislocalization of opsins, improved expression of presynaptic markers, resulted in normal length and arborization of bipolar cell dendrites, and prevented Müller cell gliosis. Although structural preservation appeared to be more pronounced with the con- 
A XLPRA1-H484TX@28wk
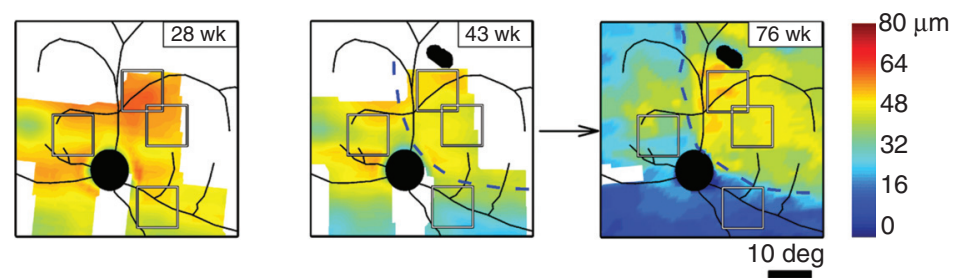

B XLPRA1

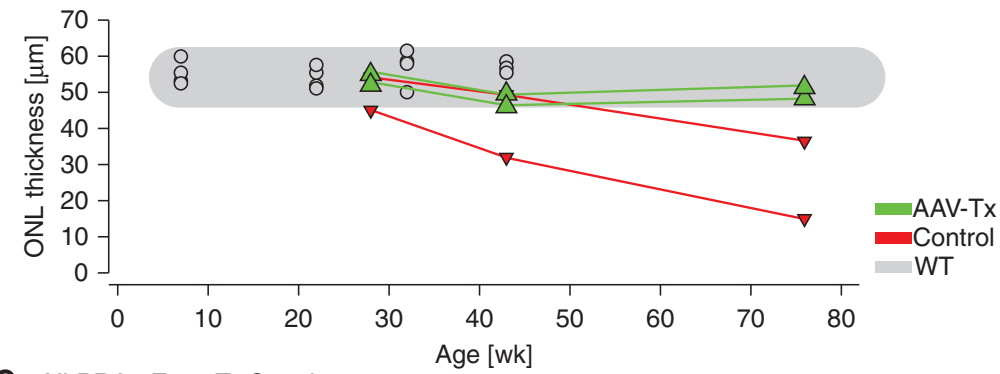

C XLPRA2-Z412Tx@5wk
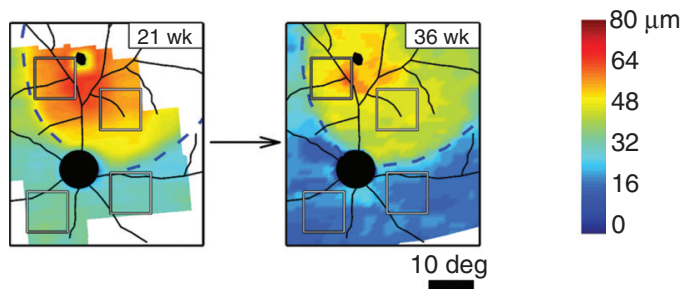

D XLPRA2

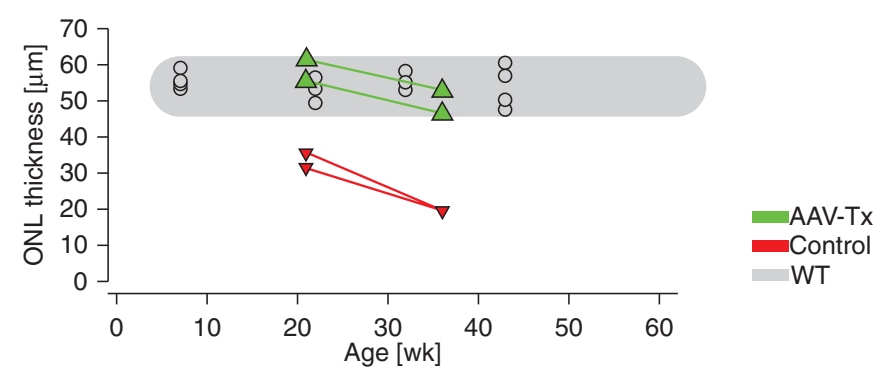

Figure 3. In vivo retinal imaging of photoreceptor rescue following gene therapy in XLPRA1 and XLPRA2 dogs. Longitudinal follow-up of outer nuclear layer (ONL) thickness changes in eyes of XLPRA1 (H484) and XLPRA2

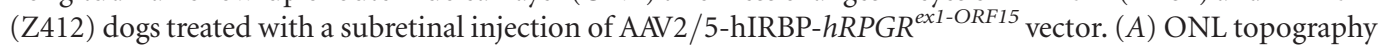
of H484 measured at 28 weeks of age, immediately before the injection, and at 43 and 76 weeks of age corresponding to 15 and 48 wk after the injection, respectively. (B) Progression of ONL thickness at regions of interest within the injection bleb (green symbols) compared with those outside the bleb (red symbols); results from wild-type animals measured at the same retinal locations are also shown (gray symbols). (C) ONL topography of Z412 measured at 21 and 36 weeks of age; injection was performed at 5 weeks of age. $(B, D)$ Progression of ONL thickness at regions of interest within the injection bleb (green symbols) compared with those outside the bleb (red symbols); results from wild-type animals measured at the same retinal locations are also shown (gray symbols). (D) Progression of ONL thickness at regions of interest within the injection bleb (green symbols) compared with those outside the bleb (red symbols); results from wild-type animals measured at the same retinal locations are also shown (gray symbols). Dashed lines in $(A)$ and $(C)$ demarcate the transient blebs created by the subretinal injections; retinal blood vessels and optic nerve are superimposed on the pseudocolor ONL data. Squares in $(A)$ and $(C)$ denote the two regions of interest chosen within the bleb boundary and two regions chosen outside the bleb boundary for the quantitative measures shown in $(B)$ and $(C)$. (Modified from data in Figures 2 and S1 from Beltran et al. 2012). 
W.A. Beltran et al.
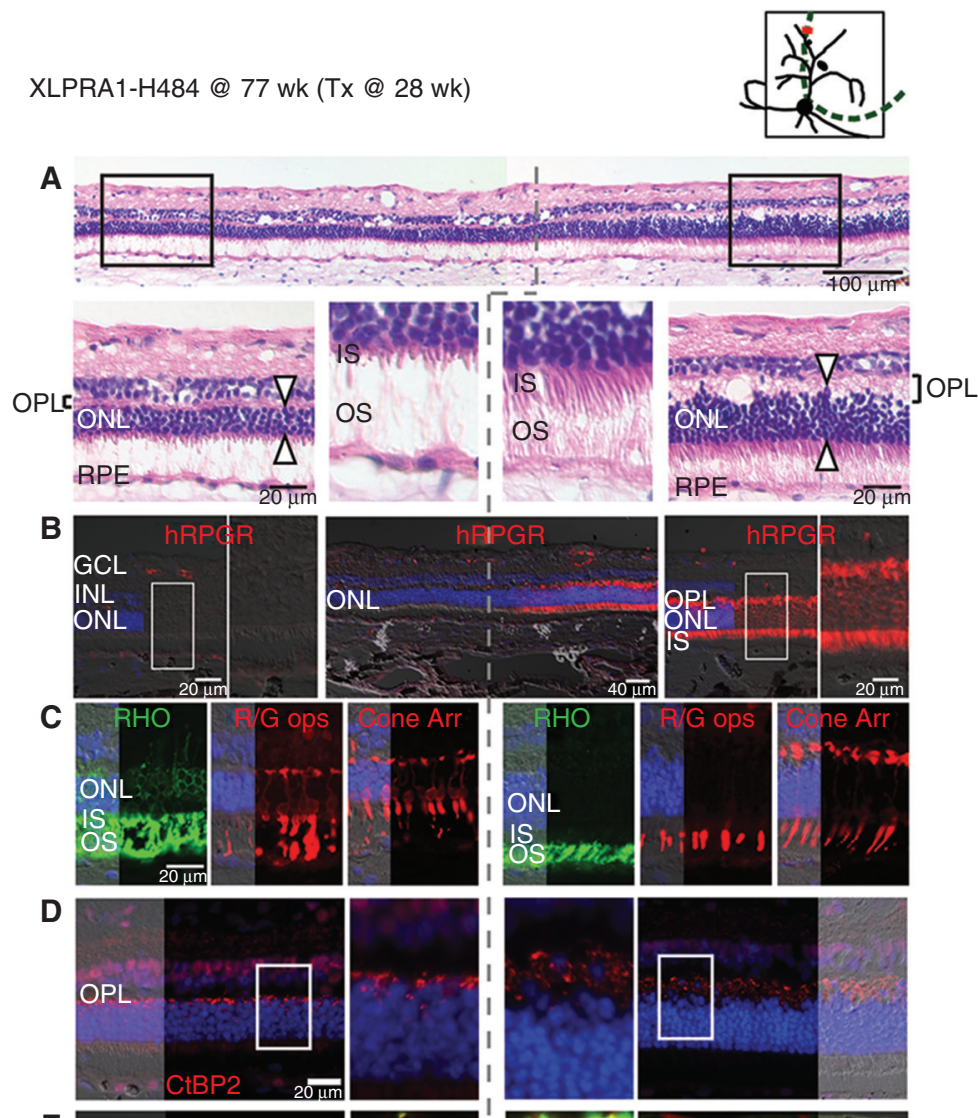

E
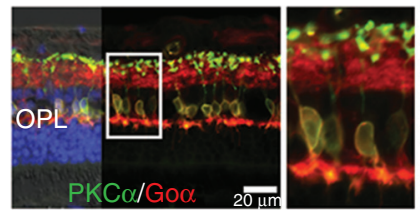

$\mathbf{F}$
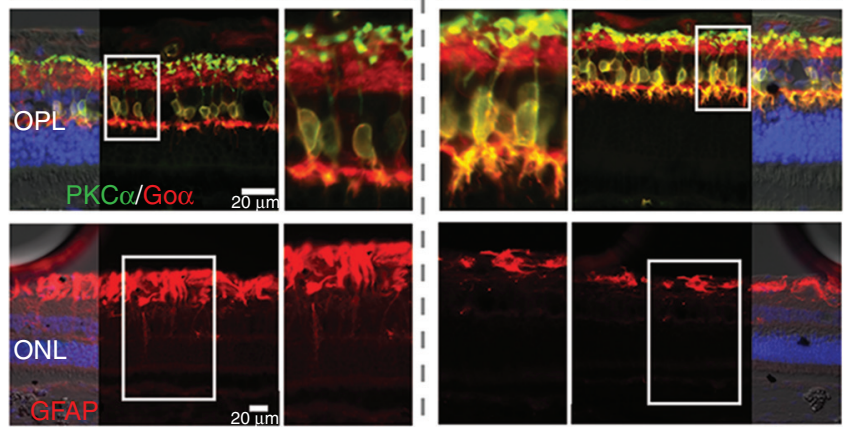

Figure 4. Gene augmentation therapy with AAV2/5-hIRBP- $h R P G R^{\text {exl-ORF15 }}$ vector prevents retinal degeneration onset in XLPRA1 disease. Upper right diagram shows the area of subretinal injection performed at 28 weeks of age (green dotted line), and the site of the histological sections shown below at 77 weeks of age (red line) in XLPRA1 dog H484. (A) H\&E stained cryosection shows preserved outer nuclear layer (ONL) thickness and inner (IS) and outer segment (OS) structure in the treated region. Dotted gray line shows the abrupt demarcation between the treated and untreated regions. (B) RPGR immunolabeling confirms expression of the transgene exclusively in the photoreceptors of the treated area. $(C)$ Mislocalization of rod opsin (RHO, green) and red/ green cone opsin $(\mathrm{R} / \mathrm{G}$, red) as well as cone morphology (cone arrestin, red) is corrected in the treated area. (D) Preserved density of CtBP2/RIBEYE immunolabeled (red) synaptic ribbons in photoreceptor terminals and normal thickness of the outer plexiform layer (OPL) in the treated area. (E) Preserved dendritic arborization in rod bipolar cells immunolabeled with PKC $\alpha$ (green) and Go $\alpha$ (red) in the treated area. (F) Absence of Müller cell reactivity assessed by GFAP (red) immunolabeling in the treated area. (Modified from data in Figures 3 and S4 from Beltran et al. 2012). 


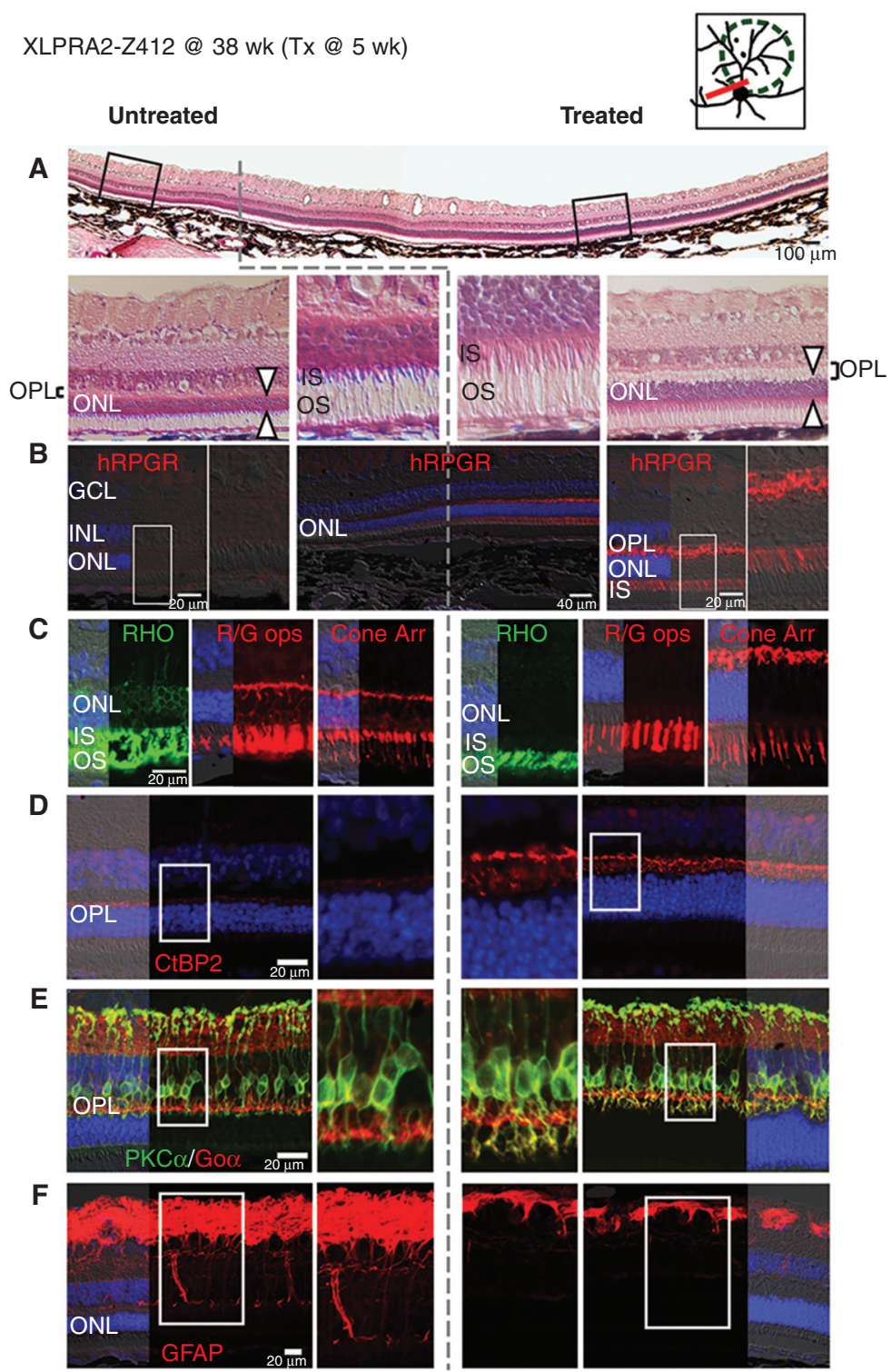

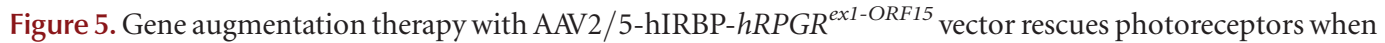
delivered at early-stage of XLPRA2 disease. Upper right diagram shows the area of subretinal injection performed at 5 weeks of age (green dotted line), and the site of the histological sections shown below at 38 weeks of age (red line) in XLPRA2 dog Z412. (A) H\&E stained cryosection shows increased outer nuclear layer (ONL) thickness and inner (IS) and outer segment (OS) structure in the treated region. Dotted gray line shows the abrupt demarcation between the treated and untreated regions. (B) RPGR immunolabeling confirms expression of the transgene exclusively in the photoreceptors of the treated area and is seen throughout the cells with the exception of the outer segments. $(C)$ Mislocalization of rod opsin (RHO, green) and red/green cone opsin (R/G, red) as well as cone morphology (cone arrestin, red) is corrected in the treated area. (D) Increased density of CtBP2/ RIBEYE immunolabeled (red) synaptic ribbons in photoreceptor terminals and increased thickness of the outer plexiform layer (OPL) in the treated area. $(E)$ Preserved dendritic arborization in rod bipolar cells immunolabeled with PKC $\alpha$ (green) and Go $\alpha$ (red) in the treated area. $(F)$ Absence of Müller cell reactivity assessed by GFAP (red) immunolabeling in the treated area. (Modified from data in Figures S3 and 4 from Beltran et al. 2012). 
W.A. Beltran et al.

struct that included the hIRBP rather than the hGRK1 promoter, both viral vectors rescued photoreceptor- and postreceptoral electroretinogram function (Beltran et al. 2012). Comparative studies including higher numbers of animals and dose groups are warranted to adequately establish which of these two promoters is optimal.

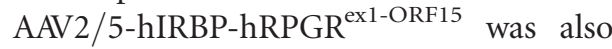
delivered to three 12-wk-old XLPRA2 dogs at mid-stage disease. At this age, the outer nuclear layer thickness is $\sim 70 \%$ of normal, retraction of rod bipolar cells has begun, and there is increased reactivity of Müller cells (Beltran et al. 2006). This is right after the peak of photoreceptor cell death and just before the beginning of the "chronic" phase of cell death, during which numerous proapoptotic and prosurvival genes are differentially expressed (Genini et al. 2013). Dogs were regularly evaluated by noninvasive retinal imaging (scanning confocal laser ophthalmoscopy and spectral-domain optical coherence tomography) and electroretinography at 39 and 42 weeks of age, respectively. Although better rescue was achieved in an agematched XLPRA2 dog treated at five weeks of age (early disease stage), both increased outer nuclear layer thickness in the bleb area and improved electroretinogram function in the treated eye of all three dogs suggest that gene therapy intervention may be beneficial even in retinal areas that have lost $>30 \%$ of their photoreceptors (Beltran et al. 2013). Ongoing studies are assessing the efficacy of therapeutic intervention at more advanced stages of disease, and whether a long-term beneficial effect can be sustained (Beltran et al. 2014b).

Positive response to gene augmentation (alone) in the early onset and rapidly progressive XLPRA2 disease challenges the original assumption that the causative frameshift mutation leads to photoreceptor cell loss through toxic gain-of-function of the mutant $\mathrm{RPGR}^{\mathrm{ex} 1-\mathrm{ORF} 15}$ isoform. A more plausible hypothesis might be that the XLPRA2 mutation results in a loss-of-function that severely impairs photoreceptor maturation and survival, whereas the XLPRA1 disease may be caused by a hypomorphic mutation that impairs long- term rod and cone viability. While these preclinical findings in two naturally occurring large animal models of RPGR-XLRP provide confidence that a similar $R P G R$ gene augmentation strategy may be effective and sufficient in treating patients with a wide variety of $R P G R$ mutations, one must remain open to the possibility that a subset of mutations may cause photoreceptor death via a toxic gain-of-function mechanism, and would require instead a combined gene knockdown and gene replacement strategy.

\section{CONCLUDING REMARKS}

Availability of two complementary canine models that recapitulate distinct spatiotemporal features of the phenotypes reported in human RPGR-XLRP patients has enabled us to establish initial proof of concept that a corrective gene augmentation approach may be sufficient to both prevent and stop the degenerative process of rods and cones. These results have provided invaluable information about the viral constructs currently being considered. Indeed, there was initially concern that fine-tuning of the levels of RPGR transgene expression in photoreceptors may be required via supposedly less "active" promoters (e.g., the RGPR promoter [Shu et al. 2012]) than the ones currently used. Yet, the potent hRPGR immunolabeling that was observed with hIRBP and hGRK1 promoters was not limited to the connecting cilium region of transduced canine rods and cones, thus suggesting that some degree of $h R P G R^{\text {ex1-ORF15 }}$ overexpression is tolerable and does not induce measurable cytotoxicity. A similar conclusion can be inferred on the basis of the normal retinal phenotype reported in transgenic mouse overexpressing RPGR ${ }^{\mathrm{ORF} 15}$ (Wright et al. 2011).

These initial proof-of-concept studies in large animals are very encouraging but will need to be monitored over a longer time period. Indeed, recent evidence in patients as well as in dogs treated by gene augmentation for the RPE65 form of Leber congenital amaurosis showed that, despite persistent functional rescue, ongoing photoreceptor loss continues (Cideciyan et al. 2013). Ongoing studies in mu- 
tant dogs should also identify the latest stage of disease that can still respond to gene therapy. Careful extrapolation of these stages from dogs to humans could provide valuable inclusion criteria for the recruitment of patients to future clinical trials. Assessing the effects of $R P G R$ gene augmentation in wild-type dogs also needs to be investigated in preparation for investigational new drug-enabling preclinical safety studies. RPGR overexpression in the wild-type retina will also inform as to whether similar gene therapy intervention could be safely considered for some carrier female patients. Finally, pursuing detailed phenotypic characterization of XLRP patients (Jacobson et al. 1997; Lorenz et al. 2003; Aleman et al. 2007; Huang et al. 2012) is necessary to establish valid outcome measures of therapeutic efficacy for future human clinical trials.

\section{ACKNOWLEDGMENTS}

Supported by National Institutes of Health Grants EY-06855, EY-17549, EY-007961, EY021721, P30 EY-001583, and 2PNEY018241, the Foundation Fighting Blindness, a Fight for Sight Nowak family grant, the Midwest Eye Banks and Transplantation Center, the Macula Vision Research Foundation, the Chatlos Foundation, Inc., the Van Sloun Fund for Canine Genetic Research, and Hope for Vision.

A patent application on AAV-mediated gene therapy for RPGR X-linked retinal degeneration has been filed (PCT/US2013/022628). W.W.H. and the University of Florida have a financial interest in the use of AAV therapies, and own equity in a company (AGTC Inc.) that might, in the future, commercialize some aspects of this work.

\section{REFERENCES}

Adamian M, Pawlyk BS, Hong DH, Berson EL. 2006. Rod and cone opsin mislocalization in an autopsy eye from a carrier of X-linked retinitis pigmentosa with a Gly436Asp mutation in the RPGR gene. Am J Ophthalmol 142: 515518.

Aguirre GD, Yashar BM, John SK, Smith JE, Breuer DK, Hiriyanna S, Swaroop A, Milam AH. 2002. Retinal histo- pathology of an XLRP carrier with a mutation in the RPGR exon ORF15. Exp Eye Res 75: 431-443.

al-Ubaidi MR, Font RL, Quiambao AB, Keener MJ, Liou GI, Overbeek PA, Baehr W. 1992. Bilateral retinal and brain tumors in transgenic mice expressing simian virus 40 large T antigen under control of the human interphotoreceptor retinoid-binding protein promoter. J Cell Biol 119: $1681-1687$.

Aleman TS, Cideciyan AV, Sumaroka A, Schwartz SB, Roman AJ, Windsor EA, Steinberg JD, Branham K, Othman M, Swaroop A, et al. 2007. Inner retinal abnormalities in $\mathrm{X}$-linked retinitis pigmentosa with RPGR mutations. Invest Ophthalmol Vis Sci 48: 4759-4765.

Andreasson S, Ponjavic V, Abrahamson M, Ehinger B, Wu W, Fujita R, Buraczynska M, Swaroop A. 1997. Phenotypes in three Swedish families with X-linked retinitis pigmentosa caused by different mutations in the RPGR gene. Am J Ophthalmol 124: 95-102.

Ayyagari R, Demirci FY, Liu J, Bingham EL, Stringham H, Kakuk LE, Boehnke M, Gorin MB, Richards JE, Sieving PA. 2002. X-linked recessive atrophic macular degeneration from RPGR mutation. Genomics 80: 166-171.

Bader I, Brandau O, Achatz H, Apfelstedt-Sylla E, Hergersberg M, Lorenz B, Wissinger B, Wittwer B, Rudolph G, Meindl A, et al. 2003. X-linked retinitis pigmentosa: RPGR mutations in most families with definite $\mathrm{X}$ linkage and clustering of mutations in a short sequence stretch of exon ORF15. Invest Ophthalmol Vis Sci 44: 1458-1463.

Bauer S, Fujita R, Buraczynska M, Abrahamson M, Ehinger B, Wu W, Falls TJ, Andreasson S, Swaroop A. 1998. Phenotype of an $\mathrm{X}$-linked retinitis pigmentosa family with a novel splice defect in the RPGR gene. Invest Ophthalmol Vis Sci 39: 2470-2474.

Beltran WA. 2009. The use of canine models of inherited retinal degeneration to test novel therapeutic approaches. Vet Ophthalmol 12: 192-204.

Beltran WA, Hammond P, Acland GM, Aguirre GD. 2006. A frameshift mutation in RPGR exon ORF15 causes photoreceptor degeneration and inner retina remodeling in a model of X-linked retinitis pigmentosa. Invest Ophthalmol Vis Sci 47: 1669-1681.

Beltran WA, Wen R, Acland GM, Aguirre GD. 2007. Intravitreal injection of ciliary neurotrophic factor (CNTF) causes peripheral remodeling and does not prevent photoreceptor loss in canine RPGR mutant retina. Exp Eye Res 84: 753-771.

Beltran WA, Acland GM, Aguirre GD. 2009. Age-dependent disease expression determines remodeling of the retinal mosaic in carriers of RPGR exon ORF15 mutations. Invest Ophthalmol Vis Sci 50: 3985-3995.

Beltran WA, Boye SL, Boye SE, Chiodo VA, Lewin AS, Hauswirth WW, Aguirre GD. 2010. rAAV2/5 gene-targeting to rods:dose-dependent efficiency and complications associated with different promoters. Gene Ther 17: $1162-$ 1174.

Beltran WA, Iwabe S, Fajardo D, Boye SE, Teng W-T, Hauswirth WW, Lewin AS, Aguirre GD. 2011. rAAV-mediated gene delivery of truncated canine RPGR causes photoreceptor dysplasia in dogs with RPGR-ORF15 stop mutation. Association for Research in Vision and Ophthalmology, 1-5 May, E-abstract 1418, Fort Lauderdale, FL. 
W.A. Beltran et al.

Beltran WA, Cideciyan AV, Lewin AS, Iwabe S, Khanna H, Sumaroka A, Chiodo V, Fajardo DS, Roman AJ, Deng WT, et al. 2012. Gene therapy rescues photoreceptor blindness in dogs and paves the way for treating human X-linked retinitis pigmentosa. Proc Natl Acad Sci 109: 2132-2137.

Beltran WA, Cideciyan AV, Lewin AS, Iwabe S, Boye S, Hauswirth WW, Jacobson SG, Aguirre GD. 2013. Corrective gene therapy for RPGR-XLRP rescues a canine model at mid-stage disease. Association for Research in Vision \& Ophthalmology, 5-9 May, E-abstract 2707, Seattle, WA.

Beltran WA, Cideciyan AV, Guziewicz KE, Iwabe S, Swider M, Scott EM, Savina SV, Ruthel G, Stefano F, Zhang L, et al. 2014a. Canine retina has a primate fovea-like bouquet of cone photoreceptors which is affected by inherited macular degenerations. PLoS ONE 9: e90390. doi:10.1371/ journal.pone/ 0090390 .

Beltran WA, Cideciyan AV, Lewin AS, Iwabe S, Swider M, Guzman JM, Boye SL, Hauswirth WW, Jacobson SG, Aguirre GD. 2014b. RPGR gene augmentation delivered at early, mid and late stage disease in a canine model of XLRP rescues photoreceptor function and structure. Association for Research in Vision \& Ophthalmology, 4-8 May, E-abstract 3321, Orlando, FL.

Berendschot TT, DeLint PJ, van Norren D. 1996. Origin of tapetal-like reflexes in carriers of X-linked retinitis pigmentosa. Invest Ophthalmol Vis Sci 37: 2716-2723.

Boylan JP, Wright AF. 2000. Identification of a novel protein interacting with RPGR. Hum Mol Genet 9: 2085-2093.

Branham K, Othman M, Brumm M, Karoukis AJ, AtmacaSonmez P, Yashar BM, Schwartz SB, Stover NB, Trzupek $\mathrm{K}$, Wheaton $\mathrm{D}$, et al. 2012. Mutations in RPGR and RP2 account for $15 \%$ of males with simplex retinal degenerative disease. Invest Ophthalmol Vis Sci 53: 8232-8237.

Breuer DK, Yashar BM, Filippova E, Hiriyanna S, Lyons RH, Mears AJ, Asaye B, Acar C, Vervoort R, Wright AF, et al. 2002. A comprehensive mutation analysis of $R P 2$ and $R P G R$ in a North American cohort of families with $\mathrm{X}$ linked retinitis pigmentosa. Am J Hum Genet 70: 15451554.

Brunner S, Skosyrski S, Kirschner-Schwabe R, Knobeloch KP, Neidhardt J, Feil S, Glaus E, Luhmann UF, Ruther K, Berger W. 2010. Cone versus rod disease in a mutant $R p g r$ mouse caused by different genetic backgrounds. Invest Ophthalmol Vis Sci 51: 1106-1115.

Bukowy-Bieryllo Z, Zietkiewicz E, Loges NT, Wittmer M, Geremek M, Olbrich H, Fliegauf M, Voelkel K, Rutkiewicz E, Rutland J, et al. 2013. RPGR mutations might cause reduced orientation of respiratory cilia. Pediatr Pulmonol 48: 352-363.

Chang B, Khanna H, Hawes N, Jimeno D, He S, Lillo C, Parapuram SK, Cheng H, Scott A, Hurd RE, et al. 2006. In-frame deletion in a novel centrosomal/ciliary protein CEP290/NPHP6 perturbs its interaction with RPGR and results in early-onset retinal degeneration in the $r d 16$ mouse. Hum Mol Genet 15: 1847-1857.

Cideciyan AV, Jacobson SG. 1994. Image analysis of the tapetal-like reflex in carriers of X-linked retinitis pigmentosa. Invest Ophthalmol Vis Sci 35: 3812-3824.

Cideciyan AV, Jacobson SG, Beltran WA, Sumaroka A, Swider M, Iwabe S, Roman AJ, Olivares MB, Schwartz SB, Komaromy AM, et al. 2013. Human retinal gene therapy for Leber congenital amaurosis shows advancing retinal degeneration despite enduring visual improvement. Proc Natl Acad Sci 110: E517-E525.

Demirci FY, Rigatti BW, Wen G, Radak AL, Mah TS, Baic CL, Traboulsi EI, Alitalo T, Ramser J, Gorin MB. 2002. Xlinked cone-rod dystrophy (locus COD1): Identification of mutations in RPGR exon ORF15. Am J Hum Genet 70: 1049-1053.

Ebenezer ND, Michaelides M, Jenkins SA, Audo I, Webster AR, Cheetham ME, Stockman A, Maher ER, Ainsworth JR, Yates JR, et al. 2005. Identification of novel RPGR ORF15 mutations in X-linked progressive cone-rod dystrophy (XLCORD) families. Invest Ophthalmol Vis Sci 46: 1891-1898.

Fahim AT, Bowne SJ, Sullivan LS, Webb KD, Williams JT, Wheaton DK, Birch DG, Daiger SP. 2011. Allelic heterogeneity and genetic modifier loci contribute to clinical variation in males with X-Linked retinitis pigmentosa due to RPGR mutations. PLoS ONE 6: e23021.

Fishman GA. 1978. Retinitis pigmentosa. Genetic percentages. Arch Ophthalmol 96: 822-826.

Fishman GA, Grover S, Jacobson SG, Alexander KR, Derlacki DJ, Wu W, Buraczynska M, Swaroop A. 1998. $\mathrm{X}$-linked retinitis pigmentosa in two families with a missense mutation in the RPGR gene and putative change of glycine to valine at codon 60. Ophthalmology 105: 22862296.

Flaxel CJ, Jay M, Thiselton DL, Nayudu M, Hardcastle AJ, Wright A, Bird AC. 1999. Difference between RP2 and $\mathrm{RP} 3$ phenotypes in $\mathrm{X}$ linked retinitis pigmentosa. $\mathrm{Br} \mathrm{J}$ Ophthalmol 83: 1144-1148.

Gakovic M, Shu X, Kasioulis I, Carpanini S, Moraga I, Wright AF. 2011. The role of RPGR in cilia formation and actin stability. Hum Mol Genet 20: 4840-4850. doi: 10.1371/journal.pone/0085408.

Genini S, Beltran WA, Aguirre GD. 2013. Up-regulation of tumor necrosis factor superfamily genes in early phases of photoreceptor degeneration. PLOS ONE 8: e85408.

Ghosh AK, Murga-Zamalloa CA, Chan L, Hitchcock PF, Swaroop A, Khanna H. 2011. Human retinopathy-associated ciliary protein retinitis pigmentosa GTPase regulator mediates cilia-dependent vertebrate development. Hum Mol Genet 19: 90-98.

Guyon R, Pearce-Kelling SE, Zeiss CJ, Acland GM, Aguirre GD. 2007. Analysis of six candidate genes as potential modifiers of disease expression in canine XLPRAl, a model for human X-linked retinitis pigmentosa 3. Mol Vis 13: 1094-1105.

Hong DH, Pawlyk BS, Shang J, Sandberg MA, Berson EL, Li T. 2000. A retinitis pigmentosa GTPase regulator (RPGR)-deficient mouse model for X-linked retinitis pigmentosa (RP3). Proc Natl Acad Sci 97: 3649-3654.

Hong DH, Yue G, Adamian M, Li T. 2001. Retinitis pigmentosa GTPase regulator (RPGRr)-interacting protein is stably associated with the photoreceptor ciliary axoneme and anchors RPGR to the connecting cilium. J Biol Chem 276: 12091-12099.

Hong DH, Pawlyk B, Sokolov M, Strissel KJ, Yang J, Tulloch B, Wright AF, Arshavsky VY, Li T. 2003. RPGR isoforms in photoreceptor connecting cilia and the transitional zone of motile cilia. Invest Ophthalmol Vis Sci 44: 2413-2421. 
Hong DH, Pawlyk BS, Adamian M, Li T. 2004. Dominant, gain-of-function mutant produced by truncation of RPGR. Invest Ophthalmol Vis Sci 45: 36-41.

Hong DH, Pawlyk BS, Adamian M, Sandberg MA, Li T. 2005. A single, abbreviated RPGR-ORF15 variant reconstitutes RPGR function in vivo. Invest Ophthalmol Vis Sci 46: $435-441$.

Huang WC, Wright AF, Roman AJ, Cideciyan AV, Manson FD, Gewaily DY, Schwartz SB, Sadigh S, Limberis MP, Bell $\mathrm{P}$, et al. 2012. RPGR-associated retinal degeneration in human X-Linked RP and a murine model. Invest Ophthalmol Vis Sci 53: 5594-5608.

Iannaccone A, Breuer DK, Wang XF, Kuo SF, Normando EM, Filippova E, Baldi A, Hiriyanna S, MacDonald CB, Baldi F, et al. 2003. Clinical and immunohistochemical evidence for an $\mathrm{X}$ linked retinitis pigmentosa syndrome with recurrent infections and hearing loss in association with an RPGR mutation. J Med Genet 40: el18.

Iannaccone A, Wang X, Jablonski MM, Kuo SF, Baldi A, Cosgrove D, Morton CC, Swaroop A. 2004. Increasing evidence for syndromic phenotypes associated with RPGR mutations. Am J Ophthalmol 137: 785-786.

Jacobson SG, Yagasaki K, Feuer WJ, Roman AJ. 1989. Interocular asymmetry of visual function in heterozygotes of X-linked retinitis pigmentosa. Exp Eye Res 48: 679-691.

Jacobson SG, Buraczynska M, Milam AH, Chen C, Jarvalainen M, Fujita R, Wu W, Huang Y, Cideciyan AV, Swaroop A. 1997. Disease expression in X-linked retinitis pigmentosa caused by a putative null mutation in the RPGR gene. Invest Ophthalmol Vis Sci 38: 1983-1997.

Jay M. 1982. On the heredity of retinitis pigmentosa. $\mathrm{Br} \mathrm{J}$ Ophthalmol 66: 405-416.

Jin ZB, Liu XQ, Hayakawa M, Murakami A, Nao-i N. 2006. Mutational analysis of RPGR and RP2 genes in Japanese patients with retinitis pigmentosa: Identification of four mutations. Mol Vis 12: 1167-1174.

Keith CG, Denton MJ, Chen JD. 1991. Clinical variability in a family with X-linked retinal dystrophy and the locus at the RP3 site. Ophthalmic Paediatr Genet 12: 91-98.

Khanna H, Hurd TW, Lillo C, Shu X, Parapuram SK, He S, Akimoto M, Wright AF, Margolis B, Williams DS, et al. 2005. RPGR-ORF15, which is mutated in retinitis pigmentosa, associates with SMC1, SMC3, and microtubule transport proteins. J Biol Chem 280: 33580-33587.

Khanna H, Davis EE, Murga-Zamalloa CA, Estrada-Cuzcano A, Lopez I, den Hollander AI, Zonneveld MN, Othman MI, Waseem N, Chakarova CF, et al. 2009. A common allele in RPGRIP1L is a modifier of retinal degeneration in ciliopathies. Nat Genet 41: 739-745.

Koenekoop RK, Loyer M, Hand CK, Al Mahdi H, Dembinska O, Beneish R, Racine J, Rouleau GA. 2003. Novel $R P G R$ mutations with distinct retinitis pigmentosa phenotypes in French-Canadian families. Am J Ophthalmol 136: $678-687$.

Komaromy AM, Varner SE, de Juan E, Acland GM, Aguirre GD. 2006. Application of a new subretinal injection device in the dog. Cell Transplantation 15: 511-519.

Komaromy AM, Alexander JJ, Cooper AE, Chiodo VA, Acland GM, Hauswirth WW, Aguirre GD. 2008. Targeting gene expression to cones with human cone opsin promoters in recombinant AAV. Gene Ther 15: 1049-1055.
Linari M, Ueffing M, Manson F, Wright A, Meitinger T, Becker J. 1999. The retinitis pigmentosa GTPase regulator, RPGR, interacts with the delta subunit of rod cyclic GMP phosphodiesterase. Proc Natl Acad Sci 96: 13151320.

Lorenz B, Andrassi M, Kretschmann U. 2003. Phenotype in two families with RP3 associated with RPGR mutations. Ophthalmic Genet 24: 89-101.

Mavlyutov TA, Zhao H, Ferreira PA. 2002. Species-specific subcellular localization of RPGR and RPGRIP isoforms: Implications for the phenotypic variability of congenital retinopathies among species. Hum Mol Genet 11: 18991907.

Mears AJ, Hiriyanna S, Vervoort R, Yashar B, Gieser L, Fahrner S, Daiger SP, Heckenlively JR, Sieving PA, Wright $\mathrm{AF}$, et al. 2000. Remapping of the RP15 locus for X-linked cone-rod degeneration to Xp11.4-p21.1, and identification of a de novo insertion in the RPGR exon ORF15. Am J Hum Genet 67: 1000-1003.

Meindl A, Dry K, Herrmann K, Manson F, Ciccodicola A, Edgar A, Carvalho MR, Achatz H, Hellebrand H, Lennon A, et al. 1996. A gene (RPGR) with homology to the $R C C 1$ guanine nucleotide exchange factor is mutated in X-linked retinitis pigmentosa (RP3). Nat Genet 13: 35-42.

Moore A, Escudier E, Roger G, Tamalet A, Pelosse B, Marlin S, Clement A, Geremek M, Delaisi B, Bridoux AM, et al. 2006. RPGR is mutated in patients with a complex $\mathrm{X}$ linked phenotype combining primary ciliary dyskinesia and retinitis pigmentosa. J Med Genet 43: 326-333.

Murga-Zamalloa CA, Atkins SJ, Peranen J, Swaroop A, Khanna H. 2010a. Interaction of retinitis pigmentosa GTPase regulator (RPGR) with RAB8A GTPase: Implications for cilia dysfunction and photoreceptor degeneration. Hum Mol Genet 19: 3591-3598.

Murga-Zamalloa CA, Desai NJ, Hildebrandt F, Khanna H. 2010b. Interaction of ciliary disease protein retinitis pigmentosa GTPase regulator with nephronophthisis-associated proteins in mammalian retinas. Mol Vis 16: 13731381.

Neidhardt J, Glaus E, Barthelmes D, Zeitz C, Fleischhauer J, Berger W. 2007. Identification and characterization of a novel RPGR isoform in human retina. Hum Mutat 28: 797-807.

Otto EA, Loeys B, Khanna H, Hellemans J, Sudbrak R, Fan S, Muerb U, O’Toole JF, Helou J, Attanasio M, et al. 2005. Nephrocystin-5, a ciliary IQ domain protein, is mutated in Senior-Loken syndrome and interacts with RPGR and calmodulin. Nat Genet 37: 282-288.

Pelletier V, Jambou M, Delphin N, Zinovieva E, Stum M, Gigarel N, Dollfus H, Hamel C, Toutain A, Dufier JL, et al. 2007. Comprehensive survey of mutations in RP2 and $R P G R$ in patients affected with distinct retinal dystrophies: Genotype-phenotype correlations and impact on genetic counseling. Hum Mutat 28: 81-91.

Petersen-Jones SM, Bartoe JT, Fischer AJ, Scott M, Boye SL, Chiodo V, Hauswirth WW. 2009. AAV retinal transduction in a large animal model species: Comparison of a self-complementary AAV2 $/ 5$ with a single-stranded AAV2/5 vector. Mol Vis 15: 1835-1842.

Roepman R, van Duijnhoven G, Rosenberg T, Pinckers AJ, Bleeker-Wagemakers LM, Bergen AA, Post J, Beck A, 
W.A. Beltran et al.

Reinhardt R, Ropers HH, et al. 1996. Positional cloning of the gene for X-linked retinitis pigmentosa 3: Homology with the guanine-nucleotide-exchange factor RCC1. Hum Mol Genet 5: 1035-1041.

Roepman R, Bernoud-Hubac N, Schick DE, Maugeri A, Berger W, Ropers HH, Cremers FP, Ferreira PA. 2000. The retinitis pigmentosa GTPase regulator (RPGR) interacts with novel transport-like proteins in the outer segments of rod photoreceptors. Hum Mol Genet 9: 2095-2105.

Ruddle JB, Ebenezer ND, Kearns LS, Mulhall LE, Mackey DA, Hardcastle AJ. 2009. RPGR ORF15 genotype and clinical variability of retinal degeneration in an Australian population. Br J Ophthalmol 93: 1151-1154.

Sandberg MA, Rosner B, Weigel-DiFranco C, Dryja TP, Berson EL. 2007. Disease course of patients with X-linked retinitis pigmentosa due to $R P G R$ gene mutations. Invest Ophthalmol Vis Sci 48: 1298-1304.

Schmid F, Glaus E, Cremers FP, Kloeckener-Gruissem B, Berger W, Neidhardt J. 2010. Mutation- and tissue-specific alterations of RPGR transcripts. Invest Ophthalmol Vis Sci 51: 1628-1635.

Sharon D, Sandberg MA, Rabe VW, Stillberger M, Dryja TP, Berson EL. 2003. RP2 and RPGR mutations and clinical correlations in patients with $\mathrm{X}$-linked retinitis pigmentosa. Am J Hum Genet 73: 1131-1146.

Shu X, Fry AM, Tulloch B, Manson FD, Crabb JW, Khanna H, Faragher AJ, Lennon A, He S, Trojan P, et al. 2005. RPGR ORF15 isoform co-localizes with RPGRIP1 at centrioles and basal bodies and interacts with nucleophosmin. Hum Mol Genet 14: 1183-1197.

Shu X, Simpson JR, Hart AW, Zeng Z, Patnaik SR, Gautier P, Murdoch E, Tulloch B, Wright AF. 2012. Functional characterization of the human RPGR proximal promoter. Invest Ophthalmol Vis Sci 53: 3951-3958.

Strazzeri JM, Hunter JJ, Masella BD, Yin L, Fischer WS, Diloreto DA Jr, Libby RT, Williams DR, Merigan WH. 2014. Focal damage to macaque photoreceptors produces persistent visual loss. Exp Eye Res 119: 88-96.

Szamier RB, Berson EL. 1985. Retinal histopathology of a carrier of X-chromosome-linked retinitis pigmentosa. Ophthalmology 92: 271-278.

Tao W, Wen R, Goddard MB, Sherman SD, O'Rourke PJ, Stabila PF, Bell WJ, Dean BJ, Kauper KA, Budz VA, et al. 2002. Encapsulated cell based delivery of CNTF reduces photoreceptor degeneration in animal models of retinitis pigmentosa. Invest Ophthalmol Vis Sci 43: 3292-3298.

Thiadens AA, Soerjoesing GG, Florijn RJ, Tjiam AG, den Hollander AI, van den Born LI, Riemslag FC, Bergen AA, Klaver CC. 2011. Clinical course of cone dystrophy caused by mutations in the RPGR gene. Graefes Arch Clin Exp Ophthalmol 249: 1527-1535.

Thompson DA, Khan NW, Othman MI, Chang B, Jia L, Grahek G, Wu Z, Hiriyanna S, Nellissery J, Li T, et al. 2012. Rd9 is a naturally occurring mouse model of a common form of retinitis pigmentosa caused by mutations in RPGR-ORF15. PLoS ONE 7: e35865. doi: 10.1371/journal.pone/0035865.
Vajaranant TS, Seiple W, Szlyk JP, Fishman GA. 2002. Detection using the multifocal electroretinogram of mosaic retinal dysfunction in carriers of $\mathrm{X}$-linked retinitis pigmentosa. Ophthalmology 109: 560-568.

van Dorp DB, Wright AF, Carothers AD, Bleeker-Wagemakers EM. 1992. A family with RP3 type of X-linked retinitis pigmentosa: An association with ciliary abnormalities. Hum Genet 88: 331-334.

Vervoort R, Lennon A, Bird AC, Tulloch B, Axton R, Miano MG, Meindl A, Meitinger T, Ciccodicola A, Wright AF. 2000. Mutational hot spot within a new RPGR exon in Xlinked retinitis pigmentosa. Nat Genet 25: 462-466.

Walia S, Fishman GA, Swaroop A, Branham KE, Lindeman M, Othman M, Weleber RG. 2008. Discordant phenotypes in fraternal twins having an identical mutation in exon ORF15 of the RPGR gene. Arch Ophthalmol 126: 379-384.

Weber M, Rabinowitz J, Provost N, Conrath H, Folliot S, Briot D, Cherel Y, Chenuaud P, Samulski J, Moullier P, et al. 2003. Recombinant adeno-associated virus serotype 4 mediates unique and exclusive long-term transduction of retinal pigmented epithelium in rat, dog, and nonhuman primate after subretinal delivery. Mol Ther 7: 774-781.

Weleber RG, Butler NS, Murphey WH, Sheffield VC, Stone EM. 1997. X-linked retinitis pigmentosa associated with a 2-base pair insertion in codon 99 of the RP3 gene RPGR. Arch Ophthalmol 115: 1429-1435.

Wright RN, Hong DH, Perkins B. 2011. Misexpression of the constitutive Rpgr ${ }^{\text {ex1-19 }}$ variant leads to severe photoreceptor degeneration. Invest Ophthalmol Vis Sci 52: 5189-5201.

Wright RN, Hong DH, Perkins B. 2012. Rpgr ${ }^{\mathrm{ORF} 15}$ connects to the usher protein network through direct interactions with multiple whirlin isoforms. Invest Ophthalmol Vis Sci 53: 1519-1529.

Yang Z, Peachey NS, Moshfeghi DM, Thirumalaichary S, Chorich L, Shugart YY, Fan K, Zhang K. 2002. Mutations in the RPGR gene cause X-linked cone dystrophy. Hum Mol Genet 11: 605-611.

Zahid S, Khan N, Branham K, Othman M, Karoukis AJ, Sharma N, Moncrief A, Mahmood MN, Sieving PA, Swaroop A, et al. 2013. Phenotypic conservation in patients with $\mathrm{X}$-linked retinitis pigmentosa caused by $R P G R$ mutations. JAMA Ophthalmol 131: 1016-1025.

Zeiss CJ, Acland GM, Aguirre GD. 1999. Retinal pathology of canine X-linked progressive retinal atrophy, the locus homologue of RP3. Invest Ophthalmol Vis Sci 40: 32923304.

Zhang Q, Acland GM, Wu WX, Johnson JL, Pearce-Kelling SE, Tulloch B, Vervoort R, Wright AF, Aguirre GD. 2002. Different RPGR exon ORF15 mutations in Canids provide insights into photoreceptor cell degeneration. Hum Mol Genet 11: 993-1003.

Zito I, Downes SM, Patel RJ, Cheetham ME, Ebenezer ND, Jenkins SA, Bhattacharya SS, Webster AR, Holder GE, Bird AC, et al. 2003. RPGR mutation associated with retinitis pigmentosa, impaired hearing, and sinorespiratory infections. J Med Genet 40: 609-615. 


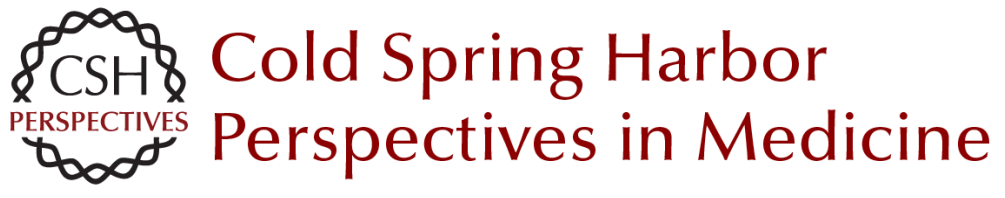

\section{Gene Augmentation for X-Linked Retinitis Pigmentosa Caused by Mutations in RPGR}

William A. Beltran, Artur V. Cideciyan, Alfred S. Lewin, William W. Hauswirth, Samuel G. Jacobson and Gustavo D. Aguirre

Cold Spring Harb Perspect Med 2015; doi: 10.1101/cshperspect.a017392 originally published online October 9, 2014

Subject Collection Retinal Disorders: Genetic Approaches to Diagnosis and Treatment

Trial by "Firsts": Clinical Trial Design and Regulatory Considerations in the Development and Approval of the First AAV Gene Therapy

Product in the United States

Kathleen Z. Reape and Katherine A. High

Immunology of Retinitis Pigmentosa and Gene Therapy-Associated Uveitis

Paul Yang, Debarshi Mustafi and Kathryn L. Pepple

Developing New Vectors for Retinal Gene Therapy

Emilia A. Zin, Bilge E. Ozturk, Deniz Dalkara, et al.

Beyond the NEI-VFQ: Recent Experience in the Development and Utilization of Patient-Reported Outcomes for Inherited Retinal Diseases

Todd Durham, Judit Banhazi, Francesco Patalano, et al.

Electronic Retinal Prostheses

Daniel Palanker

Alternative RNA Splicing in the Retina: Insights and Perspectives

Casey J. Keuthan, Sadik Karma and Donald J. Zack

X-Linked Retinoschisis

Cristy A. Ku, Lisa W. Wei and Paul A. Sieving

A Systematic Review of Optogenetic Vision Restoration: History, Challenges, and New Inventions from Bench to Bedside

Antonia Stefanov and John G. Flannery
Lessons Learned from the Development of the

First FDA-Approved Gene Therapy Drug,

Voretigene Neparvovec-rzyl

Jean Bennett and Albert M. Maguire

Therapeutic Gene Editing in Inherited Retinal

Disorders

Jinjie Ling, Laura A. Jenny, Ashley Zhou, et al.

Cell-Based Therapies: Strategies for Regeneration Marina Pavlou and Thomas A. Reh

The Importance of Natural History Studies in Inherited Retinal Diseases

Allison Ayala, Janet Cheetham, Todd Durham, et al.

Photoreceptor Cell Replacement Using

Pluripotent Stem Cells: Current Knowledge and

Remaining Questions

Christelle Monville, Olivier Goureau and Karim Ben M'Barek

iPSC-RPE in Retinal Degeneration: Recent

Advancements and Future Perspectives

Tadao Maeda and Masayo Takahashi

Retinal Degeneration Animal Models in Bardet-

Biedl Syndrome and Related Ciliopathies Clarisse Delvallée and Hélène Dollfus

Mobility Testing and Other Performance-Based Assessments of Functional Vision in Patients with Inherited Retinal Disease

Daniel Chung, Colas Authié and Laure Blouin

For additional articles in this collection, see http://perspectivesinmedicine.cshlp.org/cgi/collection/ 
For additional articles in this collection, see http://perspectivesinmedicine.cshlp.org/cgi/collection/ 